\title{
Juckes, Tim. 2012. The Parish and Pilgrimage Church of St Elizabeth in Košice - Town, Court, and Architecture in Late Medieval Hungary (Architectura Medii Aevi 6). Turnhout: Brepols. XII+292 pp. 224 figs.
}

\section{Reviewed by Marianne Sághy, Central European University (CEU), Budapest}

Tim Juckes of the Institute of Art History at the University of Vienna has written a wonderful book that Hungarian, German and Slovak scholars so far have failed to write. This work, an outgrowth of the author's $\mathrm{PhD}$ dissertation from the Courtauld Institute, is the first comprehensive scholarly monograph in any language about the largest and most ambitious Gothic construction in the medieval Kingdom of Hungary, the St. Elizabeth parish church (now cathedral) of Kassa (also called Cassovia, Kaschau), now Košice in Slovakia. This elegantly written, eminently readable study that marshals evidence and theory with admirable clarity and unfailing good cheer is, first and foremost, an architectural history, offering a thorough analysis of the phases of construction and architectural decisions taken by the patrons and master builders of this church throughout its seven hundred years of existence. Almost nonchalantly, this study also includes the best concise historical synopsis of the medieval city of Kassa available in any language (23-51); the best synthesis of the purist restoration of the church in the nineteenth century and of the beginning of Hungarian art history (5-21); and the best survey of the activity and the inspiration of the Kassa masons' lodge in Central Europe (195-214). Apart from recapitulating the findings and suggestions of earlier scholars, Juckes also formulates persuasive new hypotheses about the original functions of certain structures in the medieval church while deftly analyzing the complex socio-political networks behind this building like, e.g., the relationship among the patrons of the edifice, the town's geography, location, leaders, and population, the congregation and lodge, and the function of the church as a pilgrimage center housing the famous relic of the Holy Blood. Lapides loquuntur: Juckes reads the building as a monument that speaks to those who approach it with the right questions.

That an English-language book should be the first synthesis about this outstanding monument reinforces the odd feeling that St. Elizabeth's floats in a vacuum in today's Central Europe, apparently because the society that built and sustained it and for whom this magnificent cathedral had a meaning no longer exists; but Juckes refers only vaguely to "the intrusion of ethnic tensions into scholarship" (16) by way of accounting for the church's uniqueness and isolation. In a country whose constitution is built on the decree of Edvard Beneš (1884-1948; President of Czechoslovakia in the late 1930s and following World War II, until the communist takeover in the late 1940s) that Hungarians and Germans are "collective criminals," and where the rich, multicultural past is unscrupulously appropriated but living minorities are excluded and humiliated (the Hungarian minority in Slovakia is Europe's most endangered ethnic group), St. Elizabeth's stands like an alien meteor or a sort of Kaaba. As the multiethnic (Hungarian, German, Flemish, Polish) local burgher community that in the past sponsored, used, and

(cc) $\mathrm{Br}$

ULLS D-Serle 
Sághy, Marianne. "Juckes, Tim. 2012. The Parish and Pilgrimage Church of St Elizabeth in Košice - Town, Court, and Architecture in Late Medieval Hungary (Architectura Medii Aevi 6). Turnhout: Brepols. XII+292 pp. 224 figs." Hungarian Cultural Studies. e-Journal of the American Hungarian Educators Association, Volume 8 (2015): http://ahea.pitt.edu DOI: 10.5195/ahea.2015.200

maintained the building was wiped out from Kassa following the transition, after World War I, from historic Hungary to Slovakia, their rather natural synthesis of local languages (Hungarian, German, Slovak) disappeared as well as lost its audience. As a bothersome evidence to this process, throughout his study of a central edifice in medieval Hungary Juckes refers of course to the historic Hungary of those centuries, yet all the names of places in his book conform to the present, modern Slovak standards and overlook the fact that these Slovak names did not exist in the Middle Ages, as shown by the map of historic Hungary in this very volume (24). In this regard, the very choice of naming the church's town "Košice" in the book's title is unfortunate, as this is the present name of the city, whereas medieval St. Elizabeth's was built and later renovated in "Cassa" or "Cassovia." It would have been far better to use the historic Hungarian name or names and clarify their rationales, or even the town's ancient Latin name to avoid contemporary political complexities altogether. Strangely, Juckes only evokes a Slavic etymology for Košice, when plausible Hungarian and German etymologies explain the town's name: if Kassa is a patronym, it entirely conforms to the Hungarian toponymic habit, which is very different from the Slavic practice. Even stranger is the invention of "Abov County," as one would look for it in vain on any map: before 1918, it was Abaúj vármegye in Hungarian (whose Slovak mirror translation Abov county is), after it became Abovskoturnianska župa, and now is called Košický samosprávny kraj.

The book's first chapter summarizes the existing scholarship and documentary evidence about St. Elizabeth's Church in Košice/Kassa. The very first art historical essay about Saint Elizabeth's in Hungarian was written by Imre Henszlmann and published in Budapest in 1846. Henszlmann's essay had a direct and for us sordid impact on the church, as it led to its drastic restoration in "pure Gothic style" since the nineteenth-century Gothic revival trend preferred early to late Gothic style. As the Middle Ages were then seen as the apogee of the independent Kingdom of Hungary, "purification" as a method of resuscitating the national past was employed in order to reduce the church's architectural organism to its earliest, so-called original medieval shape. The restoration, from 1877 to 1896, was led by Imre Steindl, a disciple of the Viennese purist school, who was also the architect of the Budapest Parliament (József Sisa, Steindl Imre. Budapest: Holnap, 2005; József Sisa, "Neo-Gothic Architecture and Restoration of Historic Buildings in Central Europe: Friedrich Schmidt and His School," Journal of the Society of Architectural Historians 61 (2002), 170-187; Christopher Lang, "East Central Europe: National Identity and International Perspective," Journal of the Society of Architectural Historians 61 (2002), 519-529).

The renewal project was one of the most important endeavors of the early days of Hungarian monument preservation in that it celebrated the Hungarian identity and the millennium of the Magyar conquest of the Carpathian Basin. The structure of the church was fundamentally altered: the original arches were replaced by pointed ones, the western gallery was altered altogether, additional piers were inserted into the transept arcade, the stellar patterns of the vaults were changed into net and simple cross-rib vaults, and all post-medieval furnishings were removed. Alterations to the church exterior were somewhat less dramatic: the west and south facades were enriched with additional ornaments, and new clerestory windows in the nave and choir were added and embellished with tracery. In fact, the new parts, whose original appearance now became unknown, were simply invented. After the solemn re-consecration of St. Elizabeth's in 1896, the project ran out of funds, Steindl resigned his position in 1901, and this was the end of the restoration project. The present situation of the church as partly reconstructed 
Sághy, Marianne. "Juckes, Tim. 2012. The Parish and Pilgrimage Church of St Elizabeth in Košice - Town, Court, and Architecture in Late Medieval Hungary (Architectura Medii Aevi 6). Turnhout: Brepols. XII+292 pp. 224 figs." Hungarian Cultural Studies. e-Journal of the American Hungarian Educators Association, Volume 8 (2015): http://ahea.pitt.edu DOI: 10.5195/ahea.2015.200

presents art historians with the task of differentiating the work of the later architects from that of the earlier builders of the church. Juckes does an outstanding job concerning the understanding of the original construction as well as provides an excellent summary of the latest project, yet his main interest is in the initial phase and in finding answers to these questions: what was the original building like? who built it? what were the builders' sources of inspiration? and how did the church function in those times?

Chapter Two presents three phases in the building of St. Elizabeth's and cites earlier scholarship as well as existing documentary evidence. Standing on the spindle-shaped main square of Kassa at the junction of the two main roads dividing the medieval town into four parts and thus dominating the town, St. Elizabeth's grew out of the ambition of the burghers of this thirteenth-century freshly privileged free royal town and from their rivalry with local landlords; in addition, it was part of a renovation project following a fire that destroyed much of the town. At first, two churches were built next to each other, one by the landlords, and another by the burghers, with a heavy competition between the two groups. In 1311, the Saxon burghers killed the lord of the town, Aba Amadé, an oligarch who had sided with Máté Csák against King Charles Robert I of Anjou (1288-1342). In return, in 1347 King Charles I's son, King Louis the Great (1326-1382), granted Kassa the privilege of becoming a free royal town. Thus the burghers were able to continue building their church and incorporated into it the church originally sponsored by Amadé. There are romantic hypotheses that Amadé's church later became or was turned into the St. Michael chapel standing next to St. Elizabeth's, but Juckes rejects these hypotheses. The author, unfortunately, does not address the question of the dedication: why did the burghers' choose Saint Elizabeth of Hungary/Thuringia for the patron saint of their church? This is a highly important issue since the cult of Saint Elizabeth spread among royal dynasties and aristocratic élites: the Kassa burghers might have been the first non-élite group to make Saint Elizabeth their heavenly intercessor.

The parish church was partly destroyed by fire sometime after 1385, when it had already gained importance as a pilgrimage center due to its famous relic of the Holy Blood. Chapter Three presents the first phase of rebuilding, which lasted about a decade between 1390 and 1400 . This phase contained an enlargement of the original plan of the thirteenth-century church, including a relatively short five-aisled design with pairs of diagonal chapels, a twin-tower at the west end, and generously proportioned transepts that lent the church an aggrandizing character. The side aisles terminated with pairs of diagonal chapels, which framed a single-aisle sanctuary. The design of the east end appears to be unique within Hungary, and indeed was rare throughout Central Europe of that period. The new St. Elizabeth's Church emerged as a revival of the classic thirteenth-century style, infused with modern-to-their-time forms at the eastern end. In retrospect it seems that the work concentrated on the parts of the new building that could be constructed without demolishing the existing structure, presumably to keep the latter parts in use. The priority must have been to reconstruct the body of the church and make it functional as soon as possible; therefore, for example, the rebuilding of its perimetral walls was given primary importance. Focus was directed toward the church's southern and western sides, making much less progress on the north side, and barely beginning any work on the eastern diagonal chapels. The intention to make the church dominate the town's main square is evident by the way it must have been raised: the ground level of the new or renovated church was higher than that of the slightly older structures around and thus corresponding to the status of an urban parish church. 
Sághy, Marianne. "Juckes, Tim. 2012. The Parish and Pilgrimage Church of St Elizabeth in Košice - Town, Court, and Architecture in Late Medieval Hungary (Architectura Medii Aevi 6). Turnhout: Brepols. XII+292 pp. 224 figs." Hungarian Cultural Studies. e-Journal of the American Hungarian Educators Association, Volume 8 (2015): http://ahea.pitt.edu DOI: 10.5195/ahea.2015.200

Chapter Four, the longest and most elaborate of the chapters in the book, deals with the second phase of rebuilding, which Juckes presumes lasted since around 1400-1405 to 1430-1440, with the ground plan and large parts of the outer walls laid out. This phase turns out to have been a period of rich experimentation. The era of King Sigismund of Luxemburg (1368-1437), whose importance came to be recognized in scholarship only in the 1970s and 1980s, stands at the core of Juckes' analysis. The artistic brilliance of this period is shown by the work of the Prague Parler workshop in the Church of Our Lady and the royal castle, both at Buda (or Ofen by its German name) and by the Vienna masons' lodges active in Pozsony (Pressburg/Bratislava) and in Sopron (Ödenburg). As for Kassa, Juckes underscores that the renovation included the reorganization of the church's interior space, including its central aisle and high vaults, the sanctuary and towers, and a whole range of decorative details. In the central aisle, piers were set further apart from each other than before, with their arcade arches broadened, all of which now allowed broader spatial integration. To the same effect, now larger bays enabled the substitution of the old cross-rib vaults with an eclectic array of star vaults. The vaults of the north portal baldachins combined tracery and star forms, while the south porch had hanging vaults, which was quite unusual in the early fifteenth century. According to Juckes, the most important achievement of the second phase was the southern transept ensemble, in which a porch was added to the south portal. In addition, the gallery in the storey above had ornate tracery balustrade and crenelated sedilia, and it was open to the interior of the transepts through a broad arch and accessed by an elaborate staircase consisting of the interlocking double-spiral design, the earliest of its type in Europe. Juckes presents an important hypothesis concerning the purpose of this gallery and suggests that it served to demonstrate the Holy Blood reliquiary during pilgrimages, whereas normally the precious relics were kept in a sacristy within the church's south tower. The author emphasizes the link between church construction and cult management in Kassa and argues that certain architectural choices, like the double spiral staircase, were made to cater for the pilgrims' needs. Similarly, the motivations of the patron burghers and the king are analyzed in the larger context of late medieval religiosity and relic cults. By contrast, interior furnishing and liturgical treasures are considered only as chronological markers of their time but their possible functions are disregarded.

As for specific and at times minute elements, basing himself on recent scholarship (e.g., Sándor Tóth, "Kaschau, Elisabethkirche, von der Westfassade her betrachtet," Müvészettörténeti Értesitő 3-4 (1993), 113-139; idem, "Kaschau, Pfarrkirche Sankt Elisabeth," Sigismundus Rex et Imperator: Kunst und Kultur zur Zeit Sigismundus von Luxemburg 1387- 1437, Ausstellungskatalog, ed. Imre Takács. Mainz: Philipp von Zabern, 2006, 652-656), Juckes argues that the painting of the Last Judgement, presently on the main tympanum, might have originally been intended for the western portal. The conventional portal crown is designed as a microarchitectural altarpiece that creates the impression of a stepped polyptich and thus offers a remarkable multimedia-like fusion of figurative and abstract sculpturing. The tracery gable of the northern façade bears three statues of Hungary's royal saints: King Stephen I (975-1038), King Ladislaus I (1040-1095), and Prince Emerich, King Stephen's son (1007-1031). The crowns of the principal portals show an elaborate compilation of a contrastive layering of forms. The north portal's extensive reliefs represent the Crucifixion, the Virgin with Mary, mother of Jacob the Lesser and Mary Magdalene, John the Evangelist accompanied by a soldier and probably lecturing to or debating with four Jews, as well as various scenes from the life of Saint Elizabeth of Hungary (1207-1231). The west portal encloses three relief scenes: the Veil of Veronica, the 
Sághy, Marianne. "Juckes, Tim. 2012. The Parish and Pilgrimage Church of St Elizabeth in Košice - Town, Court, and Architecture in Late Medieval Hungary (Architectura Medii Aevi 6). Turnhout: Brepols. XII+292 pp. 224 figs." Hungarian Cultural Studies. e-Journal of the American Hungarian Educators Association, Volume 8 (2015): http://ahea.pitt.edu DOI: 10.5195/ahea.2015.200

Pietà, and the Agony in the Garden. Juckes underscores the early fifteenth-century renovation project as the most ambitious endeavor of an intensive building activity in the Kingdom of Hungary of the time in terms of both scale and artistic quality. The Kassa masons' lodge that carried out the project was influenced by architectural experiments at that time in progress in Vienna, but they were able to execute these innovations even earlier than in Vienna (143). The work on St. Elizabeth's had a lasting regional and inter-regional impact like, for example, the recurrence and reinterpretation of some of its motifs in Kolozsvár (Clausenburg/Cluj), Segesvár (Schäßburg/Sighişoara), Brassó (Kronstadt/Braşov), and Cracow; all of which will further emulate St. Elizabeth's elements well into the sixteenth century. The comparisons of the surviving sculptural evidence in St. Elizabeth's with other religious constructions in Central and Western Europe opens up new avenues of research and make Juckes' study both a pioneer and central guide in the comparative study of late medieval architecture.

By the end of the fifteenth century, as Juckes tells us in Chapter Six, Kassa became one of the leading towns of the kingdom, with a multiethnic Hungarian, Saxon, Flemish and Slavic population of about 5,000 souls (Erik Fügedi, "Kaschau, eine osteuropäische Handelsstadt am Ende des XV. Jahrhunderts," Studia Slavica Academiae Scientiarum Hungaricae 2 (1957), 185213). With a hearty mixture of Christian piety and civic pride, the city now boasted with its stunning church. During the third phase of reconstruction (c. 1440s-1490s), once work on the church's east end was completed and proceeded to the western towers, three private chapels were added on either side of the south porch, and some new furnishings were installed. Of these, the sacrament house is the most important part as it represents a remarkable example of its type, which, together with the Perpetual Light and the Mater Dolorosa niche, is attributed to the workshop of Master Stephan.

The greatest virtue of Tim Juckes' book lies in its understanding of the church as an architectural construction as well as a source of information about patrons, masons, and congregations as well as on political and financial processes of its time and place. Just as interesting as the church itself are the people who acted in its centuries-long development, starting with the priest of the town Stephanus de Caseda, a native of Navarre, who masterminded the reconstruction of the church after its ruin by fire via obtaining a papal bull in 1402; to Johannes Hebenstreyt from Nuremberg, member of the town council and judge, who by the end of the fifteenth century turned a provincial parish church into a dazzling monument and the largest of its kind in all of medieval Hungary (155). The book dispels the concept that a splendid church of such scale must have been inspired and financed by kings. Royal privilege did boost Kassa's development and ambition, but money for the church did not come from the monarchs. The dynamic was rather the contrary: the burghers of Kassa sought to demonstrate, through their representative civic and religious construction, which stood for the entire community of the town, that they well deserved the privilege of a free royal town.

The Parish and Pilgrimage Church of St Elizabeth in Košice contains 224 black-andwhite photographs taken by the author as well as rich archival material concerning the church's original structure prior to the 1877 restoration. In addition, the book is enriched by a compendium of textual and armorial sources (217-234), an appendix of mason marks (235-244), and with a visual survey of St. Elizabeth's before the nineteenth-century restoration (245-254). These data help the reader to visually imagine the original building through its several reconstructions and thus absorb the impact of the innovations exemplified in St. Elisabeth's in the context of northern Hungary as in a wider inter-regional context. Tim Juckes has written a 
Sághy, Marianne. "Juckes, Tim. 2012. The Parish and Pilgrimage Church of St Elizabeth in Košice - Town, Court, and Architecture in Late Medieval Hungary (Architectura Medii Aevi 6). Turnhout: Brepols. XII+292 pp. 224 figs." Hungarian Cultural Studies. e-Journal of the American Hungarian Educators Association, Volume 8 (2015): http://ahea.pitt.edu DOI: 10.5195/ahea.2015.200

compelling study that I recommend as obligatory reading not only for historians of architecture but for everybody interested in cathedrals and comune (township) and in the harmonious marriage of global perspective and local pride as in that of civil and religious ideals in Central European medieval towns and cities. 